\title{
UNEVEN DISTRIBUTION OF RESOURCES FROM THE POINT OF VIEW OF GENDER EQUALITY, CHANGE OF PARADIGM AND ITS CONSEQUENCES ON THE DEVELOPMENT OF SOCIAL RELATIONS. PERSISTENT SOCIAL INEQUALITIES
}

\author{
Hermína Mareková ${ }^{1}$
}

\begin{abstract}
The phenomenon of poverty in Slovakia exists not just because of its controversial understanding from a global perspective. Since 2000, Slovakia has been one of the Member States of the OECD group, which represents the most economically developed countries in the world. The definition of poverty is problematic because it cannot be narrowed down to the problem of minimum income and poverty cannot just be a statistical figure. We understand poverty in Slovakia in the sense of an uneven distribution of resources, which has a negative impact on the development of economic, educational and socio-cultural relations in individual regions as well as on the uneven ability to use these resources. This inequality is reflected mainly in the case of women, as maternity is a lifetime handicap for women. For this reason, they become vulnerable to violence in their relationships and are regarded as less valuable and more responsible for the situation. Social disparities include debt repayment, threat of execution and rent arrears. The greatest impact on social relations was brought about by the change that occurred in the second third of the twentieth century when we witnessed the process of changing social paradigms. To address the issue in our contribution, we focus on the persisting problems of gender equality and its implications for the development of social relationships and social inequalities.

In this paper, we used the analytic and synthetic method of document processing, followed by a comparison within the issues in question, and at the same time we created a new arrangement.
\end{abstract}

UDC Classification: 304, DOI: 10.12955/cbup.v7.1408

Keywords: gender equality, social inequalities, social relations

\section{Introduction}

For a very long time, human civilization was dependent on the family, which was the only place to survive, breed, and safely raise offspring. These communities were solid, with clear rules, and each individual tried to cooperate. The rules inevitably suppressed individual interests. The family was the basic unit of existence. Individuals belonging to this smallest unit could survive. The social status of the individual in the group determined his/her roles and possibilities. The concepts of equality or equal opportunities were not taken into consideration because individual family members performed different tasks. Consequently, they had different status within the group, different rights and different responsibilities. The fulfilment of these expected obligations was considered normal in society. Existence and development within the group could only be ensured by cooperation in fulfilling the expected obligations. The priority of an individual in life was to fulfil these group interests at the expense of his/her individual interests. Now the paradigm, based primarily on biological commitment, with fixed behaviour and traditional roles, has changed. Instead of a member loyal to his/her family, an autonomous individual appears, fulfilling his/her own program. The second third of the twentieth century thus becomes a time when we can observe the process of changing social paradigms. Within this paradigm shift, value systems, traditional control systems, become pluralistic. Societal control becomes less effective, which results in a massive increase in crime. Violence and crime become a universal and everyday reality of life. In order to maintain individual existence, to realize individual choices, the paradigm based on biological commitment among the members of the group was questioned. The individual is already able to exist entirely on his/her own and does not need to be a member of the smallest group - the family.

Several authors even talk about a crisis of the traditional family. As a result of paradigm changes, there has been a significant increase in the number of children born out of wedlock and a massive increase in the number of women who have started to work. The situation on the labour market has become much harder for women. It is very difficult for a young woman to acquire a job if her future employer regards her as a potential mother. The woman becomes multiply discriminated. During childcare, male colleagues are professionally ahead of her, and even after the "maternity leave", she does not have enough opportunities for job advancement. After giving birth, the woman becomes a "serf" of her child for a lifetime. At the same time, it seems as if we completely exclude men from this care. The idea that the mother is inevitably a better parent is still dominant. There is an interiorized idea that a man cannot be a good parent (caretaker) and his presence in a child's room is perceived as

\footnotetext{
${ }^{1}$ Danubius University, Sládkovičovo, Slovakia, hermina.marekova@gmail.com
} 
something extraordinary. A young man looking after a child still tends to confuse the general public. Regarding parenthood, we must point out that at the divorce process, men are most often affected by a gender stereotype, according to which every woman is a good mother.

The woman is daily confronted or even attacked by the ideas of the perfect woman, broadcast by various media. This perfect woman is able to handle the family, the baby, the household and the job. According to advertising slogans, she can still be available as a perfect sexual object. Many women are trying to meet this social demand, but enormous efforts can often cause psychological problems in young women. The media-spread standards of a perfect, beautiful and successful woman, and may, according to experts, be very much responsible for the psychological problems of young girls, e.g. their eating disorders.

\section{Income inequality in Slovakia}

Poverty is not just a statistical figure and, both in Slovakia and the rest of the EU, the vulnerable group includes single-parent women, long-term unemployed women, people with disabilities, etc.

The poverty line is defined as $60 \%$ of the median national disposable income for a single household, i.e. EUR 348 per month. As a result, a higher-income country may also have a higher risk of poverty than a poorer country with relatively smaller income gaps. This income includes maternity and parental allowance, family allowances, as well as rental income, and taxes and levies paid. Data was made available by the Statistical Office according to a survey (SO 2017) and such measurements are regularly made by all EU countries.

According to the Slovak Academy of Sciences (SAS), in 2016 it reached 35.4\% in the Slovak Republic and $26.9 \%$ in the EU. In 2017 it was already 35.4\%. Research has shown that $52.4 \%$ of single-parent households were unable to face unexpected spending. In households with three or more children, this figure is $30.2 \%$. The reason for these unfavourable data is the lower efficiency of social transfers in Slovakia in comparison with the EU. According to new data, released by the SAS on 1 June 2018, it is evident that despite the improved economic situation of demographic groups, it is the children and women who are most at risk of income poverty in Slovakia. Every fifth child under 18 years of age is exposed to the risk of income poverty. The income poverty line in Slovakia has not changed in recent years. Compared with 2015 , it has risen by $0.4 \%$. In other words, the income inequality of households in Slovakia has not increased significantly. Less than $13 \%$ of people in Slovakia are affected by a risk of income poverty, which represents around 670,000 people whose last year's income did not exceed 348 euros per month. This ranks Slovakia among the countries with the lowest risk of poverty on a European scale. According to the research results of the Sociological Institute of the Slovak Academy of Sciences (SAS 2018), persistent income poverty among children under 18 is twice as high as in the whole population. Last year, the risk of poverty among households with three or more children was growing, and in Slovakia it was higher than the European average. According to this report, the unemployed and women are the most at risk from poverty. Most often, the labour market reflects the unequal position of women in the form of segregation, depending on the job. Women predominate in low-income sectors of the economy, such as education or health, and that is "one of the reasons why women are unable to help themselves, and therefore become vulnerable to gender violence, which is also why they feel inferior. The most important cause is the unequal, discriminatory position of women on the labour market, despite the fact that such a form of discrimination is forbidden in Slovakia" (Mareková, 2008). This gender inequality is also compounded by the frequent sexual harassment of women in the workplace, which women often tolerate in order to maintain a better-paid job. The issue of the family, as Šebestová writes (2015, p. 229), has long been the most discussed topic in almost all social disciplines. We analyze, predict, statistically identify, evaluate all possible situations regarding either a functional or dysfunctional, a mononuclear or traditional family. However, despite these efforts, we still cannot achieve at least a partial improvement in family policy, if not the optimal situation. We do not deny that the family in our society has a truly irreplaceable position in all of its functions, but we cannot fail to see how families are facing, year after year, increasingly bigger problems in financing the normal household needs. In the current family environment, undesirable phenomena such as violence and abuse of one of the family members are not rare. We are also witnessing an ever deeper decline in moral values, both within the family and the whole of society. Therefore, the issue of family function in the social environment is a never-ending topic. 
In the Slovakian environment, the cultural pattern of the patriarchy still prevails, and most of the unpaid work is done by women. Elimination of gender stereotypes from education and enforcement of a gender-sensitive approach during socialization would definitely contribute to changes.

\section{Unequal life chances of women and children - persisting social inequalities}

It is true that childbirth-triggered hormone production called oxytocin and other hormones cause a significant increase in maternal sensitivity towards a baby. However, it remains questionable whether women are born for the upbringing of children or taught to do so during their own upbringing. In recent years, numerous studies have been started on the topic of the motherhood penalty, which is clearly visible in the labour market. Correll says that we talk about the motherhood penalty when - on the same terms and conditions - a childless woman is preferred in hiring or promotion. Women with children receive a lower salary and are easily dismissed (Correll et al., 2007). Inequality of opportunities and discrimination against mothers have a negative impact on society, especially on the development of social relations. The greater part of childcare is carried out by women, and women bear the "cost" of it, while men and organizations simply do not take account of the cost of reproduction, says Acker (2007).

Women's stereotype is being reinforced. At the same time, it is mothers who decides on the future existence of society. Why should they bear children when it does not have a (expressed) value for society? Upon the birth, the woman even becomes handicapped for a lifetime, and at the slightest problem and in today's partnerships, she will be disadvantaged multiple times. Potentially after a divorce, the woman gets into an unenviable situation.

The usual image of a successful woman is a "superhero" who manages to do much more than her male equivalent. The woman who builds her career receives a lower financial rating despite her efforts; in the SR it is $78 \%$ of the wages of men. A woman who feels well in the role of a mother, is not rewarded at all. "We speak of gender discrimination if a person, for reasons of gender, does not have the same rights as a person of the other sex. Norms and quotas limit the freedom of the individual and separate natural resources asymmetrically; some norms exclude women from decision-making. Discrimination is also the cause of poverty" (Mareková, 2013, p. 15).

In an era of increased support for individuality and paradigm shift, endless possibilities for personality development have been opened seemingly to everyone. While men could apply this in practice, women in some countries are left only with theory, especially because the division of labour in the family has not changed at all. The greater part of care for the child or other members of the household remains in the responsibility of women. The woman stereotype is still being supported. Older legal standards have disappeared, but behaviour persists. It is the result of the construction of ancestral power, the division of power in the form of gender power or gender structures. The reproductive role of the woman leads to her dependence, lack of power, vulnerability to men, to the family, to the group, but especially to society. Women have less legal protection and possibilities to influence their lives.

According to research by Vidovičová and Rabušič (2003), a very strong gender attitude can be seen even in the care of seniors. It is primarily women who care for the elderly. During the divorce process the child's interests are represented by a social curator. When visiting a household, the social curator checks and evaluates the mother about things such as whether the child's food is freshly cooked, whether the house is tidy and clean. During this check - performed during the day, because otherwise the social curator would not be paid overtime - only the mother is usually present. No one asks the father whether the children have clean clothes. This reflects a very strong gender attitude, according to which women must take care of these things. This results in a virtually unspoken verdict that there is some kind of equation of a well-run household on the one hand with a good mother on the other. No father's responsibility for caring for his offspring is seen. It is almost as if we deliberately disqualified the father from responsibility for the care for his child and degraded him to a mere genetic donor.

The results of the 2009 Eurobarometer survey on perceived inequality are slightly different in the Slovak Republic from the rest of Europe. While in the EU, the differences are perceived by up to $62 \%$ of the respondents, it is only 59\% in the SR. Regarding the issue of unequal distribution of domestic work in the Slovak Republic, only 23\% of respondents said they were aware of it. Up to $33 \%$ of respondents assumed that there was a small percentage of women in top politics (EU 20\%). Persistent 
sexist views are perceived by $20 \%$ in the EU and $14 \%$ in the Slovak Republic (Eurobarometer 2009). Randomly selected data indicate a persistent historical stereotype of the views on women.

According to the National Report on Human Development in the Slovak Republic (2000), single elderly women and single women in general are in this endangered group. From the point of view of monetary poverty, single women are the poorest. We can explain this as a consequence of the income inequality of women. Sexual harassment at the workplace also contributes to income inequality, whose tolerance on the part of women is often a condition for further promotion. In addition to paid work, which is paid lower for women, there is also unpaid work performed by the overwhelming majority of women, which is often overlooked. At the same time, housework is a decisive factor in family survival. In the former socialist countries, the woman had a full-time paid job and then a second shift in the household. Without much help from outside, with no available external services, which, even if they had existed, would have been inaccessible for a large number of families. In Central and Eastern Europe, the workload for the women is 70 hours per week (paid and unpaid), and is up to 15 hours longer than for the women in Western Europe. It seems that employers prefer unencumbered workers or at least those who have to do only a minimum of household work. According to Hobson and Fahlen (2009), someone who takes care of another person (an embodied one) or who does not perform such activity (disembodied) will decide not only on the basis of his abilities or needs, but on a wider scale (a context specific approach).

In spite of these facts, an international impact is visible in Slovakia. Upon joining the EU, we are "forced" to take measures to eliminate irregularities. In this process, the National Action Plan for Women became the most important document. This document was adopted in the Slovak Republic in 1997. The document is based on the Beijing Platform adopted at the Fourth World Conference on Women in Beijing in 1995. This platform was a commitment. Since the signing of this document, 22 years have passed, but the area of human rights of women is still a complex issue, related to the economic, social, cultural and political spheres. In fact, this agenda is already 62 years old, because Slovakia signed an agreement on equal pay for equal work already in 1957 in the EC Treaty, in the socalled Treaty of Rome, which enshrined the principle of equal pay for the same work. In Art. 119, it says: "Each Member State shall ensure the application and further observance of the principle of equal pay for men and women for the same work (Mareková, 2013, p. 49). It seems though that the declaration of efforts to adhere to the principles in the international forums become only a piece of paper after returning home.

\section{Conclusion}

In the recent decades, human civilization has been undergoing a functional transformation and it is very difficult to predict the direction in which civilization will develop. We are witnessing that the "maternal handicap" is still just of a marginal interest to society. There are innumerable subtle ways women are discriminated against - from GAP (gender pay gap, the gender pay inequality) in a number of countries, through job admission differences and different career progression to dismissals from jobs - creating ever greater social inequalities. These go hand in hand with the society's denial of responsibility for the existing state of affairs. The question remains whether we have achieved enough in this area over the past period and whether we could have achieved even more. As far as research is concerned, the methods differ. The data obtained are difficult to generalize, because each human being is unique in terms of personality, social environment, mental abilities and hierarchy of life values. It is difficult to achieve the same level of organization, systematicity of objectivity, measurability and verifiability in human behavioural and survival research as it is possible in the research of biological and physical phenomena.

\section{References}

Acker, J. (2007). A „társadalmi nem és szervezetek“ irányzat jövője: kapcsolódások és határvonalak [The future trends in "gender and organizations": Connections and boundaries]. In Beáta Nagy (Eds.) Szervezet, menedzsment és nemek [Organization, Management and Gender], (pp. 1-30). Budapest: Aula kiadó.

Correll, S. J., Bernard, S., \& Paik, I. Getting a job: Is there a motherhood penalty? American Journal of Sociology, 112(5), 1297-1339. Chicago: The University of Chicago Press. http://dx.doi.org/10.1086/511799

Džambazovič, R., Filadelfiová, J., Haulíková, L., Jurzyca, E., Miháliková, S., Plačintár, E., Rosa, V., Szomolányi, S., Šimúnková, K., Vagač, L., Vašečka, M., \& Kisztmer, M. (2000). Národná správa o l’udskom rozvoji. Slovenská republika 2000 [National Report on Human Development: Slovak Republic 2000]. Available at http://www.cphr.sk/undp2000.htm 
European Commission (2009). EUROBAROMETER 72: Public opinion in the EU: National Report: Executive Summary: Slovak Republic]. [online]. Brussels: TNS Opinion \& Social. [cit. 06.03.2018] Available at http://ec.europa.eu/commfrontoffice/publicopinion/archives/eb/eb72/eb72_sk_en_exec.pdf

Hobson, B., \& Fahlén, S. (2009). Competing scenarios for European fathers: Applying Sen's capabilities and agency framework to work-family balance. Annals of the American Academy of Political and Social Science, 624(1), $214-233$. http://dx.doi.org/10.1177/0002716209334435

Mareková, H. (2008). Násilie v rodine a sociálna práca: Rodové násilie. [Domestic violence and social work: Gender violence]. (Dissertation thesis, supervisor Libuša Radková; 75-61-9). Trnava: Trnava University, Faculty of Health Care and Social Work.

Mareková, H. (2013). Glosár pojmov rodovej rovnosti, rovnosti príležitostí a rodovo citlivej sociálnej práce pre sociálnych pracovnikov [Glossary of gender equality, equal opportunities and gender-sensitive social work for social workers]. Trnava. Oliva.

Slovak Academy of Sciences (2018). Annual Report 2017. [online]. Bratislava: SAS. [cit. 12.03.2018]. Available at https://www.sav.sk/php/download_doc.php?doc_no=8113

Statistical Office of the Slovak Republic /SO/. (2017). EU SILC 2016: Indikátory chudobya sociálneho vylúčenia. / EU SILC 2018 Poverty indicators and social exclusion. [online; bilingual]. Bratislava: SO. [cit. 26.07.2017]. Download available at https://slovak.statistics.sk/PortalTraffic/fileServlet?Dokument=e58d5f92-f7cd-4daa-a5ea-9fa016010f73

Šebestová, P. (2012). Problematika rodiny - „Never ending story“ [Family issues: Never-ending story]. In J. Gabura, O. Bočáková, \& P. Šebestová (Eds.) Perspektívy súčasnej rodiny: Zbornik z vedeckej konferencie s medzinárodnou účastou konanej dňa 12. septembra 2012 v Sládkovičove [Perspectives of the Modern Family: Proceedings from a conference with international attendance held on $12^{\text {th }}$ September 2012 in Sládkovičovo]. [CD-Rom]. Sládkovičovo: Fakulta sociálnych štúdií, Katedra sociálnej práce VŠS.

Šimúnková, K. (1999). Podoby chudoby na Slovensku: Chudoba a sociálna exklúzia [online]. In Džambazovič, R., Filadelfiová, J... Národná správa o l’udskom rozvoji Slovenská republika 2000 [National Report on Human Development: Slovak Republic 2000] (pp. 77-106). [cit. 15.01.2018]. Available at http://www.cphr.sk/undp2000sl_06_cast3.pdf

Vidovičová, L., \& Rabušic, L. (2003). Senioři a sociálni opatření v oblasti stárnutí v pohledu české veřejnosti: Zpráva z empirického výzkumu [The elderly and the social care in the area of aging from the viewpoint of the Czech public]. [online]. Brno: Research Institute for Labour and Social Affairs-VÚPSV. [cit. 15.03.2018]. Available at https://docplayer.cz/42398Seniori-a-socialni-opatreni-v-oblasti-starnuti-v-pohledu-ceske-verejnosti.html 